\title{
South Korea's COVID-19 Infection Status: From the Perspective of Reconfirmation after Complete Recovery
}

\author{
Yun-Jung Kang ${ }^{1 *}$ (D) and Hyunjoo Joo $^{2}$ \\ ${ }^{1}$ Department of Clinical Laboratory Science, Sang-ji University, Wonju 26339, Republic of Korea. \\ ${ }^{2}$ Department of Preventive Medicine, College of Medicine, Dankook University, Cheonan 31116, \\ Republic of Korea.
}

\begin{abstract}
COVID-19 started to occur in South Korea by an inflow of the virus from abroad, when a traveler from Wuhan, China, was first confirmed on January 19th, 2020. Although South Korea reduced the number of newly confirmed cases and is on the way to stabilizing the situation with its disease prevention policies, problems remain. The main issue is the reconfirmation of the virus after recovery. South Korean experts believe the reconfirmed cases are caused by reactivation of the virus inside the patients' body, rather than by virus reinfection after recovery. When considering reconfirmed COVID-19 cases, it is important to keep social distancing even after treating the infection. Despite no cases of reconfirmed patients infecting others having been reported yet, reexamination of patients after recovery is thought to be pivotal to prevent reactivation.
\end{abstract}

Keywords: Complete recovery, COVID-19, reactivation, reconfirmed, social distancing

*Correspondence: Ivpig@naver.com; +82-33-738-8081

(Received: April 25, 2020; accepted: May 19, 2020)

Citation: Kang Y J, Joo H. South Korea's COVID-19 Infection Status: From the Perspective of Reconfirmation after Complete Recovery. J Pure Appl Microbiol. 2020;14(suppl 1):1073-1075. doi: 10.22207/JPAM.14.SPL1.46

(C) The Author(s) 2020. Open Access. This article is distributed under the terms of the Creative Commons Attribution 4.0 International License which permits unrestricted use, sharing, distribution, and reproduction in any medium, provided you give appropriate credit to the original author(s) and the source, provide a link to the Creative Commons license, and indicate if changes were made. 


\section{INTRODUCTION}

On December 315t, 2019, a severe acute respiratory syndrome, coronavirus 2 , SARSCoV-2, was first discovered from pneumonia patients with unknown causes in Wuhan, China. After about a month, the virus spread rapidly throughout mainland China ${ }^{1}$. Later, cases of what would be termed COVID-19, were also confirmed in neighboring Asian countries, including South Korea $^{2}$. By March $10^{\text {th }}, 2020$, COVID-19's strong infectivity affected about 118,000 patients and killed more than 4,200 people around the world, resulting in the WHO to declare the situation a pandemic on March $11^{\text {th }}, 2020^{3}$. SARSCoV-2 is a type of beta-coronavirus originating from animals, with $86.9 \%$ genetic homology with bat SARS-like coronavirus ${ }^{4}$. There are four genera in coronaviridae, which include SARS-CoV-2. Among these genera, alpha and beta infect humans and other animals. The 229E, OC43, NL63, and HKU human coronaviruses are mostly seasonal, respiratory viruses which cause minor upper airway infections. In contrast, SARS-coronavirus and MERS-coronavirus, which belong to the betacoronavirus group, result in severe pneumonia.

Since mid-February 2020 in South Korea, mass infection has occurred among religious groups and residents of long-term care facilities in Daegu and Gyeongsangbukdo ${ }^{5}$. In response, the South Korean government increased its infectious disease crisis warning to 'serious' on February $23^{\text {rd }}, 2020^{6}$. South Korea announced a policy of early identification of suspected COVID-19 cases, along with policies of early isolation and treatment. Furthermore, the country promoted national action guides and practiced active prevention via social distancing. As a result of these efforts, the total number of confirmed cases on April $17^{\text {th }}$ was 10,635 , with $7,829(73.6 \%)$ among them released from quarantine. With 22 new cases confirmed and 72 new people released from quarantine, the overall number of patients quarantined has declined. Despite this progress, reconfirmation of the virus after recovery continues to occur. Since the first reconfirmation case was reported on April $8^{\text {th }}, 2020$, the total number of such cases after on April $17^{\text {th }}$ was 163 , which make up $2.1 \%$ of the total 7,829 patients released (Table 1). Women occupy a bigger proportion of reconfirmed cases, with only 54 males (33.1\%) and
109 females (66.9\%) making up the total. Among different age groups, patients between 20-29 years old occupy the largest number at $23.3 \%$. It took 13.5 days on average from the date of release to reconfirmation (min. 1-max. 35 days). Research on 137 reconfirmed cases with clinical and epidemiological information showed that 61 patients $(43.9 \%)$ had only minor symptoms. No secondary infections were reported until now. On the April $14^{\text {th }}$, the Central Disease Control Headquarters organized and distributed guidelines titled "Measures for Dealing with Reconfirmation Cases" to manage reconfirmed patients. The group is also planning to complement management measures to check the cause and infectivity of the disease, along with virus culture tests? Jaeseok Kim, an expert with the Korean Laboratory Medicine Society, suggested that patients remain quarantined in their own homes for at least two weeks even after their treatment ends, as there are cases when the virus survives asymptomatically

Table 1. Status of reconfirming COVID-19 (00:00, April $\left.17^{\text {th }}\right)$

\begin{tabular}{|c|c|c|c|}
\hline \multicolumn{2}{|c|}{ Classification } & \multirow{2}{*}{$\begin{array}{c}\text { Cases } \\
163\end{array}$} & \multirow{2}{*}{$\begin{array}{c}(\%) \\
(100.0 \%)\end{array}$} \\
\hline Total & & & \\
\hline \multirow[t]{2}{*}{ Gender } & male & 54 & (33.1\%) \\
\hline & female & 109 & (66.9\%) \\
\hline \multirow[t]{9}{*}{ Age } & $80 s \leq$ & 15 & $(9.2 \%)$ \\
\hline & $70-79 s$ & 6 & (3.7\%) \\
\hline & $60-69 s$ & 18 & $(11.0 \%)$ \\
\hline & $50-59 s$ & 32 & (19.6\%) \\
\hline & $40-49 s$ & 19 & $(11.7 \%)$ \\
\hline & $30-39 s$ & 24 & $(14.7 \%)$ \\
\hline & $20-29 s$ & 38 & (23.3\%) \\
\hline & $10-19 s$ & 6 & $(3.7 \%)$ \\
\hline & $0-9 s$ & 5 & (3.1\%) \\
\hline \multirow[t]{14}{*}{ Area } & Seoul & 7 & $(4.3 \%)$ \\
\hline & Daegu & 67 & $(41.1 \%)$ \\
\hline & Incheon & 1 & $(0.6 \%)$ \\
\hline & Daejeon & 1 & $(0.6 \%)$ \\
\hline & Ulsan & 2 & $(1.2 \%)$ \\
\hline & Sejong & 5 & (3.1\%) \\
\hline & Gyeonggi & 13 & $(8.0 \%)$ \\
\hline & Gangwon & 3 & (1.8\%) \\
\hline & Chungbuk & 2 & $(1.2 \%)$ \\
\hline & Chungnam & 3 & $(1.8 \%)$ \\
\hline & Gyeongbuk & 54 & (33.1\%) \\
\hline & Gyeongnam & 3 & $(1.8 \%)$ \\
\hline & Jeju & 1 & $(0.6 \%)$ \\
\hline & Quarantine & 1 & $(0.6 \%)$ \\
\hline
\end{tabular}


for about three to four weeks after treatment. Reactivation of COVID-19 is not limited to cases in South Korea, but is also evident in other countries. WHO emphasized this issue further, stating that people should refrain from reckless alleviation of social distancing, as patients can catch COVID-19 even after full recovery ${ }^{8}$.

Considering the reconfirmed cases of COVID-19, it is thought to be important to keep policies like social distancing in place even after treating patients. Although no incidents of reconfirmed patients infecting others has been reported yet, reexamination after complete recovery is key. As there is no established cure for the virus, both government and civil society must remain vigilant in order to reduce COVID-19 infections. Moreover, it seems that the definition of full recovery and management of the recovered patients must be updated and improved.

\section{ACKNOWLEDGMENTS}

None.

\section{CONFLICT OF INTEREST}

The listed authors declare no conflict of interest in any capacity, including competing or financial.

\section{AUTHORS' CONTRIBUTION}

The author (YJ Kang) wrote the entire manuscript and holds final responsibility for the decision to submit the manuscript for publication. The author read and approved the final manuscript

\section{FUNDING}

None.

\section{ETHICS STATEMENTS}

This article does not contain any studies with human participants or animals performed by any of the authors.

\section{AVAILABILITY OF DATA}

The datasets used and/or analyzed during the current study are available from the corresponding author on reasonable request.

\section{REFERENCES}

1. Zhu N, Zhang D, Wang W, et al. A novel coronavirus from patients with pneumonia in China, 2019. N Engl J Med. 2020;382:727-733.

2. Cheng SC, Chang YC, Fan Chiang YL, et al. First case of coronavirus disease 2019 (COVID-19) pneumonia in Taiwan. J Formos Med Assoc. 2020;119:747-751.

3. World Health Organization. WHO director-general's opening remarks at the media briefing on COVID-19 [Internet]. Geneva $(\mathrm{CH})$ : World Health Organization, c2020 [cited 2020 Apr 17]. Available from: https:// www.who.int/dg/speeches/detail/ who-directorgeneral-s-opening-remarks-at-the-mediabriefing-oncovid-19---11-march-2020.

4. Zhu N, Zhang D, Wang W, et al. A novel coronavirus from patients with pneumonia in China, 2019. N Engl J Med. 2020;382:727-733.

5. Korean Society of Infectious Diseases; Korean Society of Pediatric Infectious Diseases; Korean Society of Epidemiology; Korean Society for Antimicrobial Therapy; Korean Society for Healthcare-associated Infection Control and Prevention; Korea Centers for Disease Control and Prevention. Report on the epidemiological features of coronavirus disease 2019 (COVID-19) outbreak in the Republic of Korea from January 19 to March 2, 2020. J Korean Med Sci. 2020;35:e112.

6. Korea Centers for Diseases Control \& Prevention. Infectious disease alert level [Internet]. Cheongju (KR): Korea Centers for Diseases Control \& Prevention, c2020 [cited 2020 Apr 17]. Available from: http://ncov. mohw.go.kr/tcmBoardView. do?

brdld $=3 \&$ brdGubun $=31 \& d$ ata Gubun $=$ $\& n c v C o n t S e q=583 \&$ contSe $=583 \&$ board id=311\&gubun=ALL.

7. Korea Centers for Disease Control and Prevention; 2020 Apr 17 [cited 2020 Apr 17]. Available from: http://ncov.mohw.go.kr/ tcmBoardView. do?brdld=\&brdGubun= \&dataGubun=\&ncvContSeq= 354099 \& cont Se q = 354099 \& board id $=140 \&$ gubun $=B D J$

8. Park MW. Corona 19 Increased re-cultivation ... "Necessary revision of management regulations after completion". Medipana news; 2020 Apr 16 [cited 2020 Apr 17].

http://m.medipana.com/news_viewer. asp?NewsNum=255586\& MainKind $=$ A\&NewsKind $=$ $5 \&$ vCount $=12 \&$ vKind $=1$ 